\title{
Influence of Physical Engagement on Job Performance among Employees in the Civil Service: A Case of Kakamega Regional Head Quarters in Kenya
}

\author{
Roselyne Makhanu ${ }^{1}$, Dr. Clive Mukanzi ${ }^{2}$ and Eshiteti Stephen Nyikuli ${ }^{3^{*}}$ \\ Jomo Kenyatta University of Agriculture and Technology, Kenya \\ Received 05 Aug 2018, Accepted 08 Oct 2018, Available online 11 Oct 2018, Vol.6 (Sept/Oct 2018 issue)
}

\begin{abstract}
The purpose of this study was to investigate the influence of physical engagement on Job Performance among employees in the civil service at Kakamega regional Headquarters, Kenya. A target sample of 258 respondents drawn from a sampling comprising top, supervisory, and lower cadre employees was obtained using stratified and simple random sampling techniques. From the top management, a census was used to obtain all the 30 respondents. From the supervisory and lower cadre employees' strata, a proportionate allocation was used to select a 61 middle managers and 167 lower cadre employees (representative sample from each) and the data collected by use of questionnaires. Data was analysed using descriptive, correlation and multiple linear regression analyses. Findings of the study indicated that the civil service employees at Kakamega regional Headquarters experience high physical engagement from their superiors. As a results, it was found that their job performance had increased considerably. Further, the study also revealed a strong positive and significant correlation between physical engagement and job performance. These findings suggest that the civil service employees value the physical engagement that they receive from their workplaces which then leads to increased job performance. Therefore, the study recommends that more emphasis should be placed in ensuring the civil servants at Kakamega regional headquarters continue to be more physically engaged for enhanced job performance.
\end{abstract}

Keywords: Physical Engagement and Job Performance

\section{Introduction}

Organizational success is determined by how the organization makes effective use of the human resource (Armstrong, 2010). Hence, employee engagement is imperative in the conceptualization and measurement of the effect of human capital at the workplace including the civil service (Datche, \& Elegwa, 2015; Cattermole, Johnson \& Jackson, 2014). A lot of research has converged around one common conceptualization of employee engagement and its constructs as one that connotes high levels of human capital investment in the job performance (Rich, Lepine \& Crawford, 2010; Macey $\&$ Schneider, 2008). This engagement can be carried out through its constructs such as physical engagement.

Physical engagement has been defined as the physical participation and involvement in the organizational activities and putting effort to do work within the organization (Chughtai \& Buckley, 2008). In so doing, the employee is able to exert extra time, effort and initiative in order to contribute to the organizational success.

*Corresponding author's ORCID ID: 0000-0003-0280-7847 DOI: https://doi.org/10.14741/ijmcr/v.6.5.11
Nonetheless, engagement in employees has declined and there is a deepened disengagement among employees in organizations today (Cattermole, Johnson \& Roberts, 2013; Shuck, Rocco, Carlos \& Albornoz, 2011), despite the direct relationship that exists between employee engagement and organizational performance (Datche \& Elegwa, 2015). For purposes of this study physical engagement was characterized by the construct of work intensity and exertion of energy towards one's work.

On the other hand, job performance has been defined as a multidimensional concept by a number of authors (Motowildo, 2000). These dimensions include; task performance, contextual performance (Rich et al., 2010; Saks, 2006; Motowildo, 2000), creativity performance (Fluegge-Woolf, 2014) and role performance. This study operationalized Job performance by the constructs of task performance and role performance. Task performance is the proficiency of the individual which they usually put in use to perform certain activities which can directly or indirectly contribute to the organization's 'technical core' (Rich et al., 2010; Motowidlo \& Schmit, 1999). It is the behaviours that are involved in the production of goods and services directly or activities that provide indirect support for the organizations core technical processes 
(Werner, 2000). An emerging body of research has converged around a common conceptualization of employee engagement as predictor variable of task performance on the job (Rich et al., 2010) from which physical engagement is a key construct (Dollard \& Bakker, 2010).

\section{Statement of the Problem}

Employee engagement is on the decline at many workplaces including the civil service sector (Datche \& Elegwa, 2015). In the Kenyan civil service, employees are even unable to take on extra duties (Datche \& Elegwa, 2015; Mohammed, Abaneh \& Macky, 2015; Lee \& Galpin, 2010) leading to decreased levels of job performance, employee productivity and organizational profitability (Oluseyi, Kayode \& Morton, 2017). Furthermore, state run organizations have been said to lose between 5 per cent and 15 per cent of sales revenue because of physically disengaged employees (Juan, 2010). On the other hand, previous studies have also suggested that 87 per cent of highly engaged employees are less likely to voluntarily leave their organizations unlike their disengaged counterparts (Anitha, 2014). Incidentally, many studies have been carried out about employee engagement (e.g. Gullup, 2013) but not much literature has focused its attention on the relationship between physical engagement and Job performance. Nonetheless, there is still a clarion call for more work to be done on the constructs of employee engagement such as the physical engagement (Schaufeli, 2013). Furthermore, Macey and Schneider (2008) opined that the potential antecedents and consequences of the various types of employee engagement have not been rigorously conceptualized. Similarly, despite the continued evidence to show that employee engagement is positively linked to job outcomes, a dearth of information concerning the effect of physical engagement on job performance still exist (Mohammed et al., 2015). Therefore, this study sought to investigate the influence of physical engagement on Job performance among employees in the civil service at Kakamega HQs.

\section{Objective of the study}

To Investigate the Influence of Physical Engagement on Job Performance among Employees in the Civil Service; Case of Kakamega Regional Headquarters.

\section{Research Hypothesis}

$\mathrm{H}_{01}$ : Physical Engagement has no Significant Influence on Job Performance in the Civil Service; A Case of Kakamega Regional Headquarters.

\section{Literature Review}

Increasingly, previous researches reveal that organizations that involve high levels of physically engaged employees, tend to outperform their competitors (Cheryl \& Redfern, 2010). Accordingly, Robertson-Smith and Markwick (2012) posited that engaged employees are more likely to stay with the organization longer, increase their performance by 20 per cent beyond their colleagues' performance and always act to defend the business. In addition, such employees invest fully in their work, increase their own self-efficacy which in turn evokes their support for the organization (Mugo, Wario \& Odhiambo, 2014).

Similarly, exclusive attention to the physical component of employee engagement, posits that higher levels of physical engagement in an individual employee increases the readiness to devote effort within their work by not becoming easily fatigued and developing the tendency to remain resolute in the face of task difficulty or failure and hence increased job performance (Christian, Garza \& Slaughter, 2011; Chughtai \& Buckley, 2008). Previous researches has also shown that the physical organizational climate can affect job resources and job demands (Dollard \& Bakker, 2010), which in turn could influence personal resources (psychological experience of safety, meaningfulness, and availability), and in turn affect employee's job performance (Kahn, 1990). However, the Job demand resource theory posits that employees are especially engaged in their work when their resources are combined with challenging work demands (Bakker \& Demerouti, 2014) which may come in form of the physical engagement. Further, followers in a high-quality relationship have been found to be optimistic and selfefficacious or self-beliefs which are important predictors of work engagement (Halbesleben, 2010).

On the other hand, research on job performance has also come a long way. It is one of the most essential dependent variables which has been studied for long (Fluegge-Woolf, 2014; Jankingthong \& Rurkkhum, 2012). However, employee engagement, represents a commonality among the physical, energies which individuals bring to their work role (Fluegge-Woolf, 2014). This tends to represent the investment of multiple dimensions which includes the physical component which has also been found to lead to increased role performance (Christian et al., 2011; Rich et al., 2010; Cheryl \& Redfern, 2010). Consistently, Carnell, Ben-Hador, Waldman and Rupp (2009), Schaufeli (2013) have also opined that employee's physical engagement can enhance job performance especially among teachers, where the most engaged teacher will tend to attract more favourable ratings of performance from both the learners and their superiors.

Other explanations have also been advanced to explain the association between engagement and job performance (Bakker \& Demerouti, 2008; Bakker, Schaufeli, Leiter \& Taris, 2008). For instance, employee's physical engagement tends to elicit positive emotions which can enhance creativity, flexibility and optimism (Bakker et al., 2008). As a consequence, these individuals 
become more inclined to embrace opportunities for growth and development (Cropanzano \& Wright, 2001). Rich et al. (2010) also maintain that employee's physical engagement underpins the relationship between positive experiences at work and job performance more effectively than other outcomes such as job satisfaction, or job involvement.

In addition, Obiageli, Uzochukwu, Leo and Agu (2016) sought to investigate the extend of employee engagement and its effect on job performance. From the findings obtained, it emerged that lower cadre employees in civil service of Anambra state in Nigeria, were seriously disengaged and as such, they had their job performance greatly decreased. This was consistent with the findings of Shimazu, Schaufeli, Miyanaka and Iwata (2010) who opined that civil service workers in Japan also show low work engagement. In a cross-sectional survey that sought to explore the effects of employee engagement on organizational performance in the horticultural sector in Kenyan (Otieno, Waiganjo \& Njeru, 2015), it was found that the two variables (i.e. employee engagement and organizational performance) were positively and significantly related.

In addition, engaged employees tend to enhance more enduring forms of physical and psychological health which then facilitates their effort towards job performance. Furthermore, engaged employees are likely to uncover and accumulate resources such as information and support from colleagues (Schaufeli \& Salanova, 2011). Bakker, Schaufeli, Leiter and Taris (2008) also posited that physically engaged employees tend to inspire colleagues which then improves their performance on the jobs. Accordingly, Rich et al. (2010) conducted a research on job engagement its antecedents and effect on job performance. They theorized that employee engagement which is conceptualized as an investment in an individual's complete self, provides a more comprehensive explanation of the performance on the job. Further, the findings revealed that employee's physical engagement mediates the relationship between core self-efficacy and the dimensions of job performance; organization citizen behaviour, task performance and role performance. Similarly, another exploratory research was conducted to investigate the relationship between job characteristics of job clarity, job autonomy, job significance and job performance and employee engagement (Mugo, Wario \& Odhiambo, 2016). The findings obtained revealed that job performance as a job characteristic was significantly related to employee's physical engagement. On the overall, job characteristics were found to explain 92.5 per cent in employee's overall engagement within the state corporations in Kenya.

\section{Conceptual Framework}

A conceptual framework is a visual or a written product, that "explains, either graphically or in narrative form, the main things to be studied or the key factors, concepts, or variables and the presumed relationships among them (Ravitch \& Riggan, 2011). Accordingly, Robson (2011) described the conceptual framework as the system of concepts, assumptions, expectations, beliefs, and theories that supports and informs the research. It is therefore, a key part of the research design. The reviewed literature indicates that there is a link between employee's physical engagement and job performance (Mugo, Wario \& Odhiambo, 2014; Kanten \& Sadullahb, 2012; Jankingthong \& Rurkkhum, 2012; Rich et al., 2010). Moreover, a recent study showed that engagement in whatever form is a conduit for the effects of broader individual and workplace factors on job performance (Rich et al., 2010) as conceptualized in figure 1;

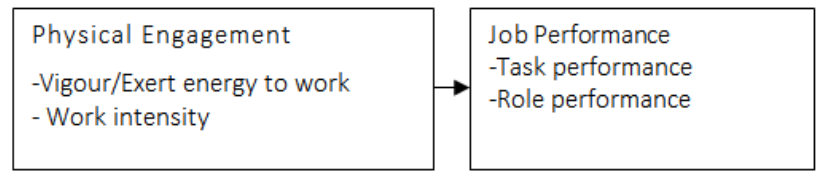

Figure 1: Conceptual Framework

The conceptual framework presented in figure 1 shows that job performance can be a function of physical engagement. Accordingly, the interplay between the predictor variables (vigour and work intensity) and could account for the increased employee's job performance in the public service in Kakamega regional headquarters in Kenya.

\section{Research Methodology}

This study adopted a descriptive research design across 14 ministry departments at Kakamega regional HQs. This design is the best available to social scientists who are interested in collecting original data for purposes of describing a population phenomenon as it exists at present (Singh, 2006). It enables researchers to obtain data about the practices or situations at one point in time through questionnaires items. Many researchers have also successfully utilized the same research design in the related fields (e.g. Rich et al., 2010). The study targeted a population of 590 employees working as civil servants in the 14 national ministries at Kakamega regional HQs and categorized into top management, supervisory and lower cadre (Public Service Report, 2016). A sample size of 258 respondents was obtained with 30 respondents obtained from the top management by a census, 61 from supervisory and 167 from lower cadre employees. Further, the sample from each stratum (61 of supervisors and 167 of lower cadre employees) was obtained by the proportionate allocation. Simple random sampling technique was used to select the sample from each stratum. Data was collected by use of a self-administered questionnaire. Both descriptive and inferential statistics of the correlation and regressions were used for the analysis. 
Table 1: Physical Engagement

\begin{tabular}{|c|c|c|c|c|c|c|}
\hline & $\begin{array}{c}\text { 5= Strongly Agree, 4= Agree, } 3=\text { Neither Agree nor disagree, } 2=\text { Disagree, } \\
\text { 1=Strongly Disagree }\end{array}$ & SA\% & $\begin{array}{l}\text { A } \\
\%\end{array}$ & $\begin{array}{l}\mathbf{N} \\
\% \\
\end{array}$ & $\begin{array}{l}\text { D } \\
\%\end{array}$ & SD\% \\
\hline 1 & My organization makes me work with intensity & 13.2 & 43.4 & 9.4 & 31.1 & 2.8 \\
\hline 2 & My organization makes me exert my full effort and energy to my job & 15.1 & 34.0 & 19.8 & 24.5 & 6.6 \\
\hline 3 & My organization makes me devote a lot of energy to my job & 19.8 & 32.1 & 12.3 & 27.4 & 8.5 \\
\hline 4 & My organization makes me strive as hard as I can to complete my job & 19.8 & 35.8 & 15.1 & 24.5 & 4.7 \\
\hline 5 & My organization always makes me feel full of energy at my work & 17.0 & 39.6 & 11.3 & 20.8 & 11.3 \\
\hline 6 & My organization makes persevere at work even when things do not go well & 15.1 & 35.8 & 19.8 & 19.8 & 9.4 \\
\hline 7 & My organization always makes me to do more than is required on my job & 18.9 & 39.6 & 10.4 & 28.3 & 2.8 \\
\hline 8 & My organization makes me feel strong and vigour when I am working & 22.6 & 34.0 & 17.0 & 20.8 & 5.7 \\
\hline 9 & My organization makes me burst with energy at work & 17.0 & 34.9 & 18.9 & 20.8 & 8.5 \\
\hline 10 & My organization has made me to become mentally resilient & 19.8 & 31.1 & 20.8 & 14.2 & 14.2 \\
\hline 11 & My organization makes me to work overtime a lot of times & 15.1 & 41.5 & 10.4 & 22.6 & 10.4 \\
\hline
\end{tabular}

\section{Results and Discussion}

Physical engagement was measured by the constructs of vigour and work intensity on a five-point likert scale from $1=$ strongly disagree to $5=$ strongly agree. The results obtained were presented in table 1.

The results in table 1 showed that a majority ( 43.4 per cent) of respondents agreed that their organizations make them work with a lot of intensity, while 13.2 per cent of them strongly agreed. However, 31.1 per cent disagreed with the statement with only 2.8 per cent strongly disagreeing with it. Furthermore, 34.0 per cent of respondents agreed that their organization makes them to exert full effort and energy on their work performance. Another 15.1 per cent strongly agreed with the same statement. On the contrary, 24.5 per cent disagreed with the same statement, and a further 6.6 per cent strongly disagreeing with it. Equally, a majority of respondents (32.1 per cent) agreed that their organization makes them devote a lot of energy on the job while another 19.8 per cent strongly agreed with the same statement. On the other hand, 27.4 per cent of the respondents disagreed with this view, while another 8.5 per cent strongly disagreed with it. In addition, another majority of respondents (35.8 per cent) agreed that the organization makes them strive hard to complete given tasks, with another 19.8 per cent strongly agreeing with the same statement. Similarly, 24.5 per cent disagreed with the same statement while another 4.7 per cent strongly disagreed with it.

Furthermore, the results in table 1 also indicated that 39.6 per cent (majority) of the respondents agreed that the organization makes them feel full of energy while at work. Another 17.0 per cent strongly agreed with the declarative statement. On the other side, 20.8 per cent were of the opinion that their organization do not make them feel full of energy while at work while another 11.3 per cent strongly disagreed with the statement. Consistently, a majority of respondents (35.8 per cent) also agreed that the organization makes them persevere even when things seem not to be going on well for them. A further 15.1 per cent of the respondents strongly agreed with this view. However, 19.8 per cent, and another 9.4 per cent did not feel that way and they opted to disagree and strongly disagree respectively.

Equally, a majority of respondents (39.6 per cent) agreed that the organization makes them to do more than what is required at work. Another 18.9 per cent strongly agreed with the statement. Nonetheless, 28.3 per cent of the respondents were of the contrary opinion, with another 2.8 per cent strongly in disagreement with the same statement. Furthermore, 34.0 per cent of the respondents also agreed that their organization makes them feel strong and with vigour when working. Further, 22.6 per cent strongly agreed that this is so. On the contrary, 20.8 per cent of the respondents disagreed with the statement and another 5.7 per cent strongly in disagreement. In a similar case, 34.9 per cent agreed that the organization makes them burst with energy while working, with another 17.0 per cent strongly agreeing with the same statement. Nevertheless, 20.8 per cent of respondents disagreed, while another 8.5 per cent of them strongly disagreed with the same statement.

The findings in table 1 also revealed that a majority of respondents (31.1 per cent) were in agreement that their own organization makes them become mentally resilient. Another 19.8 per cent strongly agreed with the same statement. On the contrary, 14.2 per cent of these respondents, simply disagreed with the statement, with another 14.2 per cent strongly disagreeing with it. Finally, 41.5 per cent of the respondents (majority) agreed that their organization makes them work overtime, while 15.1 per cent of them strongly agreed with the statement. On the other hand, 22.6 per cent of the respondents disagreed with the view, while 10.4 per cent were of the respondents strongly disagreed with the statement.

\section{Correlation Analysis}

Inferentially, the study also conducted, a correlation analysis to establish whether there is a significant relationship between physical engagement and job performance together with its constructs of task and role performance. The results obtained was as shown in table 2. 
Table 2: Correlation Matrix

Correlations

\begin{tabular}{lccccc}
\hline & & Physical Engagement & Task performance & Role performance & Job Performance \\
\hline \multirow{4}{*}{ Physical Engagement } & Pearson Correlation & 1.000 & $.802^{* *}$ & $.831^{* *}$ & $.841^{* *}$ \\
& Sig. (2-tailed) & & .000 & .000 & .000 \\
& $\mathrm{~N}$ & 106 & 106 & 106 & 106 \\
\hline \multirow{2*}{*}{ Correlation } & & & &
\end{tabular}

**. Correlation is significant at the 0.01 level (2-tailed).

The findings from table 2 indicated that the predictor variable physical engagement has a positive and significant influence on task performance $\left(r=0.802^{* *}, p<\right.$ $0.01)$, on role performance $\left(r=0.831^{* *}, p<0.01\right)$ and the overall job performance $\left(r=0.841^{* *}, p<0.01\right)$. These results corroborate the previous findings about the relationship between physical engagement and job performance by various researches (e.g. Dollard \& Bakker, 2010; Chughtai \& Buckley, 2008). According to Christian and Slaughter (2011) physically engaged employees have high levels of energy, are enthusiastic about their work and generally perform highly on their jobs. Furthermore, having a physically engaged workforce can provide a competitive edge, because engagement is an active state which is positively related to important outcomes such as job performance (Halbesleben, 2010).

\section{Regression Analysis}

To test for the amount of variation of the independent variable (physical engagement) on the dependent variable (Job Performance) together with its constructs of task and role performance, a regression analysis was also carried out. In relation to the results of the correlation matrix in table 2 , it was found that physical engagement has a strong, positive and significant influence on task performance, role performance and the overall Job performance. Nonetheless, to establish the specific nature of the influence, physical engagement (predictor variable) was regressed with the dependent variables (Task, Role and Job performances) and the results obtained presented in tables 3, 4 and 5 and interpreted thereof;

Table 3: Physical Engagement on Task Performance

\begin{tabular}{|c|c|c|c|c|c|c|c|}
\hline \multicolumn{8}{|c|}{ Model Summary } \\
\hline \multirow[t]{2}{*}{ Model } & \multirow[t]{2}{*}{$\mathrm{R}$} & \multirow[t]{2}{*}{ R Square } & \multirow[t]{2}{*}{ Adjusted R Square } & \multirow{2}{*}{$\begin{array}{c}\text { Std. Error of the } \\
\text { Estimate }\end{array}$} & \multicolumn{3}{|c|}{ Change Statistics } \\
\hline & & & & & R Square Change & F Change & Sig. F Change \\
\hline 1 & $.802^{a}$ & .644 & .640 & .70184 & .644 & 187.861 & .000 \\
\hline
\end{tabular}

Table 4: Physical Engagement on Role Performance

\begin{tabular}{cccccccc}
\multicolumn{1}{c}{ Model Summary } \\
\hline Model & $\mathrm{R}$ & R Square & Adjusted R Square & $\begin{array}{c}\text { Std. Error of the } \\
\text { Estimate }\end{array}$ & \multicolumn{3}{c}{ Change Statistics } \\
& & & & R Square Change & F Change & Sig. F Change \\
\hline 1 & $.831^{\text {a }}$ & .690 & .687 & .63271 & .690 & 231.551 & .000 \\
\hline a. Predictors: (Constant), Physical Engagement & & & &
\end{tabular}

The results in the table 3 showed the amount of variation on the dependent variable (task performance) as explained by the independent variable (physical engagement). The regression analysis that was conducted yielded a coefficient of $R$ value of 0.802 and $R^{2}=0.644$. This implied that 64.4 per cent of the corresponding variation in the predicted variable (task performance) could be explained by physical engagement. In addition, the results in table 3 gave the $F$ test value of 187.861, $p<$ 0.01 which was large enough to support the goodness of fit of the model explaining the variation in task performance. This also confirmed the usefulness of the predictor variable (physical engagement) on task performance. Therefore, from these (table 3) it was established that there is a strong, positive and significant influence of physical engagement on task performance among employees in the civil service at Kakamega regional HQs.
Equally, when physical engagement (predictor variable) was regressed with the dependent variables (Role performance), the results obtained was presented in tables 4 as shown;

Similarly, the results in the table 4 also showed the amount of variation on the dependent variables (role performance) as explained by the independent variable (physical engagement). The findings obtained yielded a coefficient of $R$ value of 0.831 and $R^{2}=0.690$. This means that 69.0 per cent of the corresponding variation in the predicted variable (role performance) could be explained by physical engagement. In addition, the results in table 4 gave the $F$ test value of $231.551, p<0.01$ which was large enough to support the goodness of fit of the mode explaining the variance in role performance. This also confirms the usefulness of the predictor variable (physical engagement) on role performance. Therefore, from the 
findings of the regression analysis (table 4) it was established that there is a strong, positive and significant influence of physical engagement on role performance among employees in the civil service at Kakamega regional HQs.
Similarly, when physical engagement (predictor variable) was regressed with the main dependent variables (job performance) in this study, the results obtained was presented in tables 5 as shown;

Table 5: Physical Engagement and Job Performance

\begin{tabular}{ccccccc}
\hline \multicolumn{1}{c}{ Model Summary } \\
\hline Model & $\mathrm{R}$ & $\mathrm{R}$ Square & $\begin{array}{c}\text { Adjusted R } \\
\text { Square }\end{array}$ & $\begin{array}{c}\text { Std. Error of the } \\
\text { Estimate }\end{array}$ & $\begin{array}{c}\text { Change Statistics } \\
\text { R Square } \\
\text { Change }\end{array}$ & $\begin{array}{c}\text { F Change } \\
\text { Sig. F Change }\end{array}$ \\
\hline 1 & $.841^{\mathrm{a}}$ & .707 & .704 & .60733 & .707 & 251.094 \\
\hline
\end{tabular}

a. Predictors: (Constant), Physical Engagement

Table 6: Coefficients of Physical Engagement

\begin{tabular}{cccccc}
\multicolumn{1}{c}{ Coefficients $^{\mathrm{a}}$} \\
\hline
\end{tabular}

a. Dependent Variable: Job Performance

The results in table 5 showed the amount of variation on the dependent variable (Job performance) as explained by the independent variable (physical engagement). The regression analysis that was conducted yielded a coefficient of $R$ value of 0.841 and $R^{2}=0.707$. This means that 70.7 per cent of the corresponding variation in the predicted variable (job performance) could be explained by physical engagement. In addition, the results in table 5 gave the $F$ test value of $251.094, p<0.01$ which was large enough to support the goodness of fit of the model explaining the variation in job performance. This also confirms the usefulness of the predictor variable (physical engagement) on job performance. Therefore, from the findings of the regression analysis (table 5) it was established that there is a strong positive and significant influence of physical engagement on job performance among employees in the civil service at Kakamega regional HQs. These findings corroborate those of the previous researches about the link of employee's physical engagement and Job performance (e.g. Christian \& Slaughter, 2011; Christian et al., 2011; Halbesleben, 2010; Chughtai \& Buckley, 2008). Furthermore, the unstandardized coefficient values were given in table 6;

The unstandardized regression coefficients $\beta$ value of the computed (composite index) scores of physical engagement was 0.948 with a t-value of 15.846 at a significance level of $p<0.01$. Since the $t$-value is greater than +1.96 , the regression model obtained in table 4.6 is confirmed to be significant and feasible. Further, with a $p$ $<0.01$ it implies that for every 1 per cent increase in physical engagement there was a predicted increase in the percentage of job performance of zero. Having achieved the objective, the study rejected the null hypothesis that; $\mathrm{H}_{01}$ : Physical engagement has no significant influence on job performance among employees in the civil service at Kakamega regional HQs in Kenya.
Hence, the regression equation model obtained from table 6, was as shown;

$\mathbf{Y}=\boldsymbol{\alpha}+\boldsymbol{\beta}_{1} \mathbf{X}_{\mathbf{1}}+\boldsymbol{\varepsilon}$ and thus, the estimated model was given by;

\section{Job Performance $($ predicted $)=0.123+0.948 *$ Physical Engagement}

\section{Limitations to Study}

The generalizability of conclusions of this study should be treated with reservations, and hence, further research may be required to allow for more robust conclusions. This is because data collection was carried out by use of self-report questionnaires which created the challenges attributed to the measurement's overreliance on responses given by specific respondents. The instrument did not seek to get the real actions about employee engagement activities on the ground. Additionally, most of the measures used in the study were of the Likert scales which were likely to create a mono method bias challenge, which is a threat to validity. This is a problem attributed to the collection of much data using the same method and/or type of scale such that the findings can then be attributed to individuals' tendencies to respond to similar types of measures in similar ways. Nonetheless, although the bias might have been a threat, it is unlikely that it may have had a serious impact on the findings since validity to the questions asked was ensured by establishing a chain of evidence from all level of employees, selecting and adapting questionnaire items from previous relevant researches, and referring the research instrument to professional judgment for checking as to whether it measured the claimed measure. 


\section{Summary, Conclusion and Recommendation}

The study sought to determine whether physical engagement influences job performance in the civil service at Kakamega regional HQs in Kenya. Physical engagement was measured by use of 11 questionnaire items on which the respondents had been asked to give the extent to which they agreed with the declarative statements asked. According to the findings of this study, it was revealed that physical engagement has a strong, positive and significant influence on job performance of $\left(R^{2}=0.841\right)$. Therefore, the corresponding alternative hypothesis that $\mathrm{H}_{1}$ : Physical engagement has a significant influence on job performance among employees in the civil service at Kakamega regional $\mathrm{HQs}$ in Kenya was supported.

\section{References}

[1]. Anitha, J. (2014). Determinants of Employee Engagement and their Impact on Employee Performance. International Journal of Productivity and Performance Management, 63 (3), 308-323

[2]. Armstrong, M. (2010). A Handbook of Human Resource Management Practice: 10 Edition. Kogan Page Limited, London.

[3]. Bakker, A. B., \& Demerouti, E. (2008). Towards a Model of Work Engagement. Career Development International, 13, 209-223.

[4]. Cattermole, G., Johnson, J., \& Jackson, D. (2014). Employee Engagement Creates a Brighter Economic Future at Jupiter Hotels. Strategic HR Review, 13 (2), 81-85.

[5]. Cattermole, G., Johnson, J., \& Roberts, K. (2013). Employee Engagement Welcomes the Dawn of an Empowerment Culture. Strategic HR Review, 12 (5), 250-254

[6]. Chughtai, A. \& Buckley, F. (2008). Work Engagement and Its Relationship with State and Trait Trust: A Conceptual Analysis. Journal of Behavioural and Applied Management. 10(1), 47-71

[7]. Cheryl, A. E., \& Redfern, C.D. (2010). How Can Employee Engagement Be Improved at The RRG Group? Part 1. Industrial and Commercial Training, 42 (5), 265-269

[8]. Christian, M. S., Garza, A. S., \& Slaughter, J. E. (2011). Work Engagement: A Quantitative Review and Test of Its Relations with Task and Contextual Performance. Personnel Psychology, 64(1), 89-136.

[9]. Christian, M.S. \& Slaughter, J.E. (2011). Work Engagement: A Meta-Analytic Review and Directions for Research in an Emerging Area, Paper Presented at the Congress Paper in 67th Annual Meeting of Academy of Management, Philadelphia, PA, 6 August.

[10]. Cropanzano, R., \& Wright, T. A. (2001). When A Happy Worker is Really A Productive Work: A Review and Further Refinement of the Happy-Productive Worker Thesis. Consulting Psychology Journal: Practice and Research, 53, 182-199.

[11]. Datche, A. E. \& Elegwa, M. (2015). The Effects of Transformational Leadership on Employee Engagement: A Survey of Civil Service in Kenya. Business Management and Economics, 3 (1), 9-16.

[12]. Fluegge-Woolf, E.R. (2014). Play Hard, Work Hard: Fun at Work and Job Performance. Management Research Review, 37(8), 682-705.
[13].Gullup (2013). Reveals Workplace Disengagement in Thailand. Gallup Management Journal,

[14]. Halbesleben, J.R.B. (2010). A Meta-Analysis of Work Engagement: Relationships with Burnout, Demands, Resources, and Consequences. Work Engagement: A Handbook of Essential Theory and Research, New York: In: A.B. Bakker and M.P. Leiter (Eds.), Psychology Press, 2010, 102-17.

[15]. Jankingthong, K. \& Rurkkhum, S. (2012). Factors Affecting Job Performance: A Review of Literature. Journal of Social Sciences, Humanities, and Arts, 12 (2), 115-127.

[16]. Kahn, W. A. (1990). Psychological Conditions of Personal Engagement and Disengagement at Work. Academy of Management Journal, 33, 692-724.

[17]. Kanten, S. \& Sadullahb, O. (2012). An Empirical Research on Relationship Quality of Work Life and Work Engagement. Procedia - Social and Behavioral Sciences, 62 (2012), 360 366

[18]. Lee W., \& Galpin, T. J. (2010). The Engagement Factor: Building A High Commitment Organization in A Low Commitment World. Journal of Business Strategy, 31 (5), $14-24$

[19]. Macey, W. H.\& Schneider, B. (2008). The Meaning of Employee Engagement. Industrial and Organizational Psychology, 1(2008), 3-30

[20]. Motowidlo, S.J. (2000). Some Basic Issues Related to Contextual Performance and Organizational Citizenship Behavior in Human Resource Management. Human Resource Management Review, 10(1), 115-126.

[21]. Mugo, K., Wario, G., \& Odhiambo, R. (2014). Relationship Between Job Characteristic and Employee Engagement Among State Corporations in Kenya. International Journal of Innovative Research and Studies, 3 (5), 326-350

[22]. Obiageli, O.L., Ozochukwu, O.C., Leo, O. \& Agu, A.I. (2016). Employee Engagement and Performance in Selected Ministries in Anambra State Civil Service of Nigeria. Journal of Economics and Public Finance, 2(2), 280-297.

[23]. Oluseyi M A, Kayode O., Morton, S. (2017). Stimulating Employee Ambidexterity and Employee Engagement in Small and Medium Enterprises. Management Decision, 55 (4), 662-680

[24]. Otieno, A. B., Waiganjo, W. E., \& Njeru, A. (2015). Effect of Employee Engagement on Organization Performance in Kenya's Horticultural Sector. International Journal of Business Administration, 6(2), 2015

[25]. Ravitch, M., \& Riggan, M. (2017). Reason \& Rigor: How Conceptual Frameworks Guide Research (2nd ed.). Thousand Oaks, CA: SAGE Publications, Inc.

[26]. Rich, B. L., LePine, J. A., \& Crawford, E. R. (2010). Job Engagement: Antecedents and Effects on Job Performance. Academy of Management Journal, 53(3), 617- 635.

[27]. Robertson-Smith, G., \& Markwick, C. (2012). Employee Engagement. A Review of the Current Thinking. Institute for Employment Studies University of Sussex Campus.

[28]. Robson, C. (2011). Real World Research. Chichester, UK: Wiley-Blackwell.

[29].Saks, A.M. (2006). Antecedents and Consequences of Employee Engagement. Journal of Managerial Psychology, 21 (7), 600-619

[30]. Schaufeli, W. B., \& Salanova, M. (2011). Work Engagement: On How to Better Catch a Slippery Concept. European Journal of Work and Organizational Psychology, 20(1), 3946. 
[31]. Schaufeli, W.B. (2013). What is engagement? In C. Truss, K. Alfes, R. Delbridge, A. Shantz, \& E. Soane (Eds.), Employee Engagement in Theory and Practice. London: Routledge

[32]. Singh, Y. (2006). Fundamentals of Research Methodology and Statistics. New Age International Limited Publishers

[33].Shimazu, A., Schaufeli, W.B., Miyanaka, D., \& Iwata, N. (2010). Why Japanese Workers Show Low Work Engagement: An Item Response Theory Analysis of the Utrecht Work Engagement Scale Biopsychosocial Medicine, 4(17), 1-6
[34].Shuck, M., Rocco, T.S. \& Albornoz, C.A. (2011). Exploring Employee Engagement from the Employee Perspective: Implications for HRD. Journal of European Industrial Training, 35 (4), 300-325.

[35].Werner, J. M. (2000). Implications of OCB and Contextual Performance for Human Resource Management. Human Resource Management Review, 10(1): 245-261. 